\title{
О ГРАНИЦЕ МЕЖДУ ЗАПАДНЫМ И ВОСТОЧНЫМ ТИПАМИ НАПРЯЖЕННОГО СОСТОЯНИЯ ПЛАТФОРМ ЕВРОПЫ
}

\section{Сим Л.А.}

Институт физики Земли им. О.Ю. Шмидта РАН, Москва, sim@ifz.ru

Неотектонические напряжения на Западно-Европейской (ЗЕП) и Восточно-Европейской (ВЕП) платформах восстановлены преимущественно двумя методами: на Балтийском щите кинематическим [1] и структурно-геоморфологическим (СГ) методом реконструкции сдвиговых перемещений [5]. С помощью СГ метода восстанавливаются ориентации осей сжатия и растяжения в горизонтальной плоскости, тип сдвигового перемещения по разломам (правый или левый), геодинамическая обстановка формирования разлома (растяжения или сжатия). Т.к. сдвиговые напряжения восстанавливаются по мелким прямолинейным элементам рельефа, которые дешифрируются в зоне динамического влияния сдвигов, то возраст восстановленных СГ методом напряжений принимается за новейший по возрасту молодых отложений, почти сплошь перекрывающих на дневной поверхности платформенный чехол. Восстановленные комплексом тектонофизических методов неотектонические напряжения на ЗЕП и ВЕП платформах выявили два типа сдвигового напряженного состояния: западный и восточный $[6,11]$. Западный тип характеризуется запад-северо-западной и широтной, восточный - субмеридиональной ориентациями осей сжатия в горизонтальной плоскости. Между разными типами напряженного проведена граница, состоящая из двух ветвей. Первая проходит на севере примерно по границе Балтийского щита и Русской плиты, далее она имеет СВ простирание, переходящее в меридиональное и проходит по западу Белорусской антеклизы практически до Восточных Карпат. Граница между западным и восточным типами напряженного состояния сместилась от ожидаемого ее совмещения с линией ТТ - границей между платформами с разновозрастным фундаментом. Сопоставление неотектонических напряжений, восстановленных СГ методом по обе стороны от линии ТТ с современным рельефом показала, что генеральные ориентации осей сжатия сохраняются субширотными в обоих крыльях разлома, а меридиональное растяжение подтверждается широтными уступами и эскарпами, выделенными С. Остафичуком [9] (рис. 1). Выделенная граница совпадает с аномалиями теплового потока [3] и, видимо, обусловлена глубинным строением литосферы в этой части ВЕП на неотектоническом этапе.
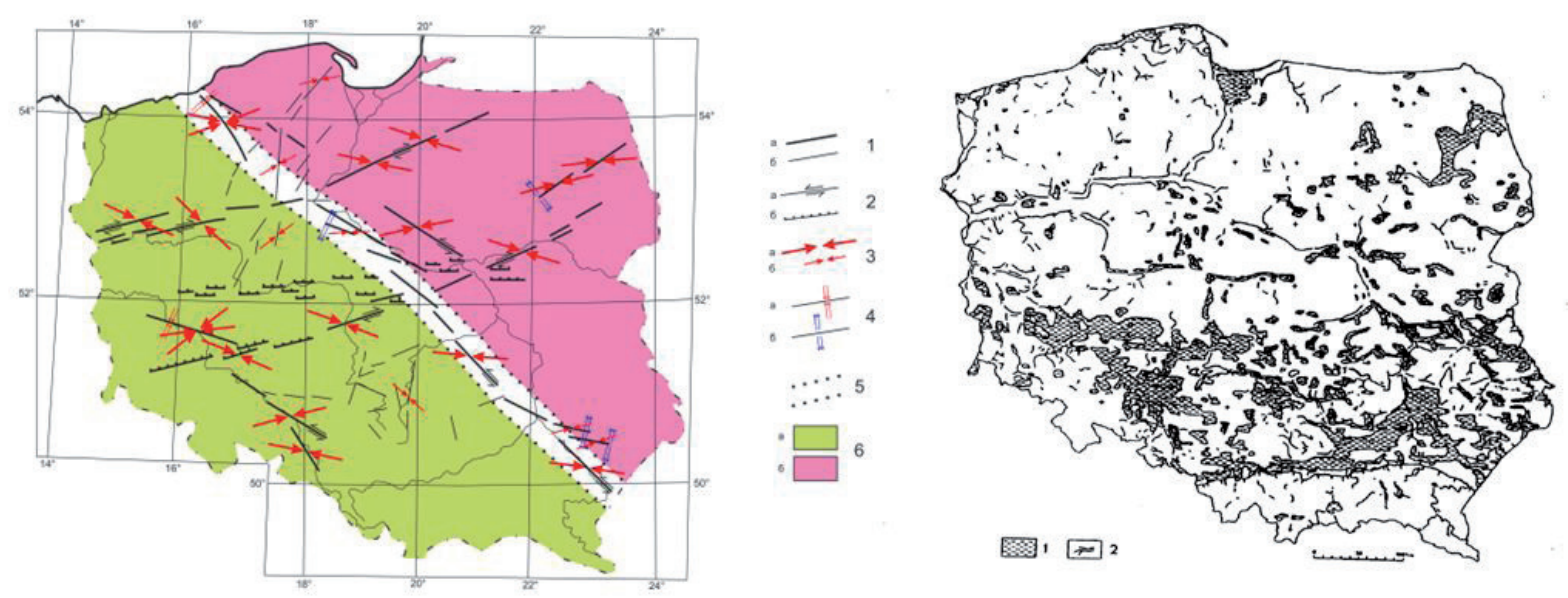

Рис. 1. Сопоставление неотектонических напряжений с особенностями рельефа Польши (по [6]).

Слева: Неотектонические напряжения, восстановленные СГ методом: 1 - разломы: а - I, б - II порядка; 2 - кинематические типы разломов: а - сдвиги, б - сбросы; 3 - Оси сжатия в горизонтальной плоскости: a - I, б - II рангов; 4 - геодинамические обстановки формирования разломов: а - сжатия, б - растяжения; 5 - зона Тейссера-Торнквиста; 6 - платформы: а - Западно-Европейская, б - Восточно-Европейская.

Справа: 1 - депрессии, 2 - эскарпы (по [9]). 
A

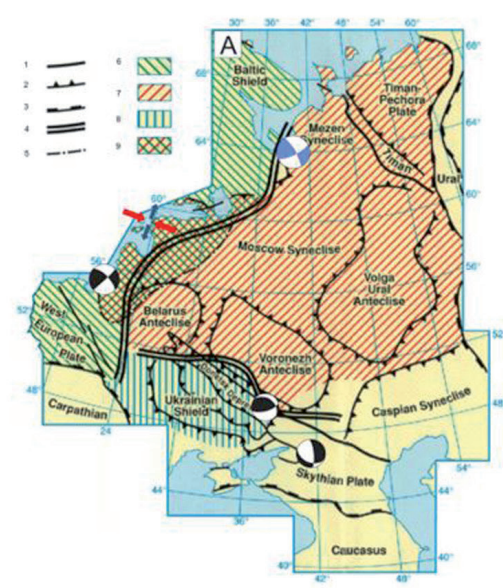

Б

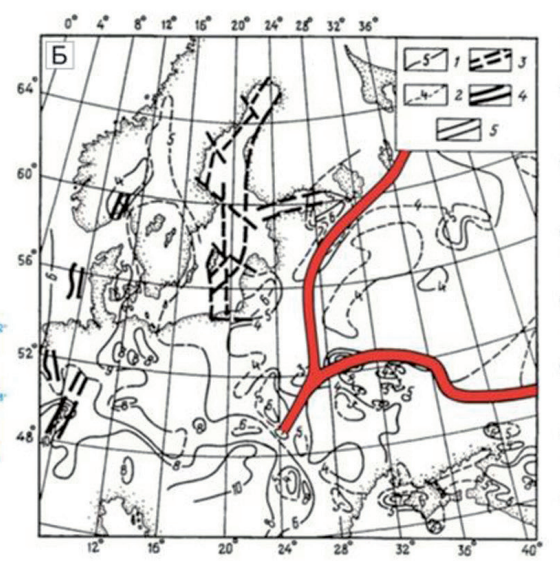

B

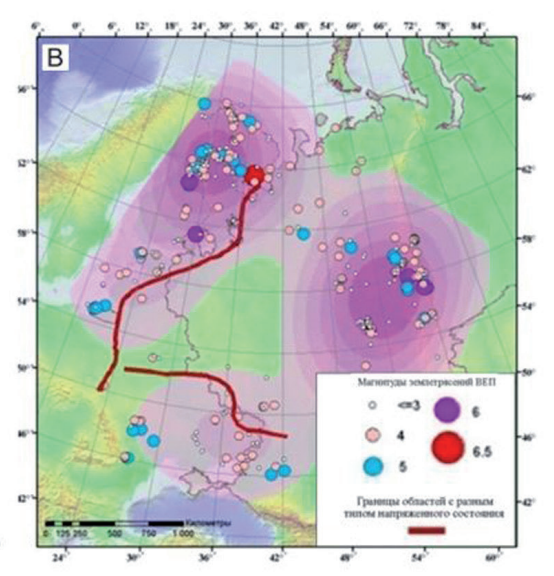

Рис. 2. Схема районирования тектонических напряжений ВЕП и структур обрамления по типу напряженного состояния (А), сопоставление границы неустойчивых напряжений с тепловым потоком (Б) и с сейсмичностью (В). А - 1-4 - границы: 1 - крупнейшие разломы, ограничивающие разновозрастный фундамент платформ; 2 - крупнейших структур платформ северной Европы; 3 - орогенных структур; 4 - между областями с разными типами ориентировок осей главных нормальных напряжений. 5-8 - Области разного типа напряженного состояния: 5 - с 3-В и ЗСЗ ориентацией осей сжатия; 6 - с С-Ю и субмеридиональной ориентацией осей сжатия; 7 - с нестабильной ориентацией осей сжатия; 8 - с обстановкой растяжения.

Б - границы неустойчивых неотектонических напряжений и тепловой поток. 1-2 - Изолинии теплового потока: 1 - уверенные, 2 - предполагаемые [по: Карта теплового..., 1987], 3-4 - крупнейшие разломы: 3 -рифтогенные, 4 - прочие. В - эпицентры землетрясений (по: [Землетрясения..., 2007].

Вдоль побережья Балтийского моря выделена специфическая область, характеризующаяся геодинамической обстановкой растяжения и неустойчивой, двойственной ориентацией осей сжатия (рис.2). Обстановка растяжения, вероятно, связана с формированием молодых грабенов Балтийского щита. Двойная ориентация осей сжатия показывает, что крупные разломы в этой области могут активизироваться в новейшем поле напряжений как правые, так и как левые сдвиги. Это может объясняться попеременным развитием грабенов субмеридионального Ботнического и субширотного Финского заливов $[6,10]$. Механизмы очагов Осмуссаарского и Калининградского землетрясений, определенных в этой области, имеют субширотную и субмеридиональную ориентации осей Р $[4,12]$, что свидетельствует и о современном режиме напряженного состояния, соответствующего восстановленным неотектоническим в этой области $[7,10]$. Обстановка растяжения в выделенной области неустойчивых напряжений подтверждается аномальной проницаемостью гелия [8]. Выделенная граница практически идеально делит области платформ на западную с очагами землетрясений и асейсмичную восточную части, что подтверждает правомерность ее выделения по ориентировкам осей сжатия (рис. 2).

Вторая ветвь границы между разными типами напряженного состояния имеет субширотное простирание, которое на юго-западном склоне Воронежской антеклизы приобретает юго-восточное простирание и на южной границе Воронежской антеклизы становится опять субширотной. С севера и востока от этой границы оси сжатия субмеридиональны, на юг и юго-запад от нее оси сжатия хаотичны преимущественно в пределах Украинского щита. Можно предположить, что хаотическая ориентировка осей сжатия на юго-запад от второй ветви неустойчивых простираний осей сжатия связана не с неотектоническим напряженным состоянием, а со спецификой трещиноватости, отпрепарированной на дневной поверхности пород кристаллического фундамента Украинского щита. В древних архей протерозойских породах, разбитых разломами с разным возрастом заложения и активизации, трещиноватость также отражает смещения по разломам, различные на разных стадиях тектонического развития территории. Вероятность определения и дешифрирования трещинова- 
тости, связанной со сдвиговыми перемещениями по разломам в неотектонический этап, невелика. Т.е. СГ метод, основанный на дешифрировании и интерпретации прямолинейных элементов рельефа, вероятно, имеет ограничения в применимости на щитах. Так, на Балтийском щите удалось определить СГ методом ориентировку главных нормальных напряжений в горизонтальной плоскости лишь на единичных разломах, заведомо активизированных на неотектоническом этапе. Например, в зоне крупного Онего-Сегозерского разлома в Центральной Карелии откартированы все признаки новейшей активности, вплоть до смещения озов, поэтому по трещиноватости взоне динамического влияния этого разлома восстановлена левосдвиговая кинематика в новейший этап. Этот тип перемещения по обсуждаемому разлому согласуется и с данными, полученными другими методами.

\section{Выводы}

На границе между разными типами ориентировки осей сжатия неотектонических напряжений выделяется зона неустойчивых тектонических напряжений. Разный тип напряженного состояния обусловлен влиянием процессов спрединга в Северной Атлантике (западный тип с 3С3 до широтной ориентировками осей сжатия) и в Арктике (восточный тип с субмеридиональной ориентацией оси сжатия). На юге Русской плиты субмеридиональное сжатие обусловлено влиянием орогенных процессов на Кавказе. Граница между разными типами неотектонического напряженного состояния обусловлена, вероятнее всего, глубинным строение земной коры.

\section{Литература}

1. Гущенко О.И. Метод кинематического анализа структур разрушения при реконструкции полей тектонических напряжений // Поля напряжений в литосфере. М.: Наука. 1979. С. 7-25.

2. Землетрясения и микросейсмичность в задачах современной геодинамики Восточно-Европейской платформы. Под ред. Н.В. Шарова и др. // Кн. 1. Землетрясения. Петрозаводск: Карельский научный центр РАН. 2007. С. 173-218.

3. Карта теплового потока Европы. Масштаб 1:6 000000 // Ред. В.В. Гордиенко. Киев. Наукова думка, 1987.

4. Никонов А.А. Калининградское платформенное землетрясение 2004 г. - вопросы решаемые и решения ожидающие // Матер. XII междунар. конф. «Активные геологические и геофиз. процессы в литосфере. Методы, средства и рез-ты изучения. Т. 2. Воронеж. 2006. С. 21-22.

5. Сим Л.А. Изучение тектонических напряжений по геологическим индикаторам (методы, результаты, рекомендации). Изв. ВУЗов. геология и разведка. 1991. № 10. С. 3-22.

6. Сим Л.А. Влияние глобального тектогенеза на новейшее напряженное состояние платформ Европы // М.В. Гзовский и развитие тектонофизики. М.: Наука. 2000. С. 326-350.

7. Сим Л.А. Области неустойчивых неотектонических напряжений на Русской плите // Связь поверхностных структур земной коры с глубинными. Матер.14-й междунар. конф. 27-31 октября 2008. Ч. 2. Петрозаводск. 2008. Ред.-изд. отд. Карельского научного центра. С. 190-193.

8. Схема проницаемости земной коры Европейской части СССР по данным гелиевых исследований. М-б 1:2500000 // Ред. А.Н. Еремеев. М. 1983.

9. Ostaficzuk S. Impact of Poland’s geological structure on neogeodynamics // Techn.posz. geol., geotsynopttyca I geotermia. 1995. N 3. S. 79-107.

10. Sim L. Neotectonic stress field of platform structures in the Baltic region // Technica Technica Poszukiwan Geol. Geosynoptica I Geotermia. Warszawa. 1999. No. 1. P. 96-101.

11. Sim L.A., Korcemagin V., Frischbutter A., Bankwitz P. The neotectonic stress field pattern of the East European Platform. Z. geol. Wiss. V. 27 (3/4). P. 161-181. Berlin. Sept. 1999

12. Slunga R. Sourse mechanism of the Baltic earthquake interred from surfasewave recordings // Bull. Seismol. Soc. Amer. 1979. V. 69. N 6. P. 1931-1964. 